\title{
Identification of Polymicrobial Infection from Necrotised Tumours
}

\author{
${ }^{1}$ Vinod Singh, Sudhir K. Jain and Archana Shrivastava \\ Department of Applied Microbiology and Laboratory Medicine, College of Life Sciences, \\ Cancer Hospital and Research Institute, Gwalior (M.P.) 474009 INDIA \\ (Received 24 April 2001; and accopted 7 June 2001)
}

\begin{abstract}
Bacteria were grown from 63 (69\%) of 91 specimens from necrotic tumours in 63 patients of the tumours 14 were abdominal, 5 pelvic, 29 of the head and neck, 4 of the lungs, 4 mediastinal, lymphatic, 3 of the breast, and 8 were miscellaneous. Aerobic or facultative anaerobic bacteria only were present in 12 (19\%) specimens, anaerobes only in $10(16 \%)$, and mixed aerobic and anaerobic bacteria in 41 (65\%). A total of 83 anaerobic and 47 aerobic and facultative anaerobic bacteria were isolated. The predominant anaerobic bacteria were Bacteroides spp. (36 isolates), and anaerobic cocci (21) and Propionobacterium acnes (22). The aerobic and facultative anaerobic bacteria most frequently isolated were Staphylococcus aureus, $\alpha$-haemolytic streptococci, Escherichia coli (seven isolates each), S. epidermidis, Klebsiella pneumniae and Pseudomonas aeruginosa (five isolates each). These data demonstrate that infection of tumours is usually polymicrobial.
\end{abstract}

Infection is one of the major obstacles to the successful management of patients with malignant tumours (3) and is often suspected in cancer patients who develop cancer especially when associated with neutropenia. Although most infections in febrile neutropenic patients are systemic, in a large number no obvious source of infection is found. Infection in the tumour mass may account for some of these febrile episodes. Although infection of necrotic tumours has been recognised, the microbiology of such infections has not been studied adequately. This study was designed to identify the bacteria present in infected solid tumours and to correlate them with tumour sites.

${ }^{1}$ Correspondence to Dr Vinod Singh, c/o Dr. A. K. Singh, Flar No. \#103, Akansha Apartments, City Center, Gwalior (M.P.), India

Tel: +91-0751-435474

Email:vsingh3@rediffmail.com

\section{MATERIALS AND METHODS}

Patients. Ninety one specimens from tumours thought to infected were obtained from 63 in patients (39 males) aged 13-74 (mean 52) years at Cancer Hospital and Research Institute, Gwalior (M.P.) India. The sites of the tumours from which tumours isolated obtained were : abdomen 14 (colon and rectum 6, liver 4, Peritoneum 2, small intestine 2); ovary 4; uterus 1 ; head and neck 23 (lymph nodes 7 , thyroid 4 , parotid and salivary glands 4, larynx 3, paranasal sinuses 3 , intracranial); lungs 4; mediastinum 4; lymphatic (axil1a and groin) 2; breast 3; and miscellaneous 8 (skin 2, muscle in extremities 2 , heart 2, kidney 1 , and adrenal). Antimicrobial therapy (penicillin in 15 patients, cephalosporins 1 , aminoglycosides 7 , and clindamycin 6) had been given to these (28) patients before sample collection. Forty-four patients had clinical signs of infection, including fever (temperature $>38.5^{\circ} \mathrm{C}$ in 31 and leucocytosis $\left(>12,000 \mathrm{wbc} / \mathrm{mm}^{3}\right)$ in 24 .

Isolation and identification of bacteria. Speci- 
mens were taken during surgery only form solid tumours suspected of being infected, by aspirating pus or by swabbing infected areas, taking care to avoid specimens were transported to the laboratory in the syringe used to collect them, capping the needle with a rubber stopper. Swabs were transported in anaerobic transport medium (PortA-Cul, BBL Microbiological Systems, Beckon Dickinson, Cockeysville, MD). The time between specimen collection and culture never exceeded 2 h. Aerobic bacteria were sought by culture on sheep blood agar, heated blood agar, and Mac Conkey' s agar plates, incubated at $37^{\circ} \mathrm{C}$, aerobically Mac Conkey's agar) or in $\mathrm{CO}_{2} 5 \%$; the plates were examined after 24 and $48 \mathrm{~h}$. To isolate anaerobic bacteria, the specimens were plated at the bench on to reduced brucella blood agar enriched with vitamin $\mathrm{K}, 10 \mathrm{mg} / \mathrm{mL}$, and vancomycin $7-5 \mathrm{mg} / \mathrm{L}$, and a blood-agar plate containing phenyl ethyl alcohol $42.5 \mathrm{~g} / \mathrm{L}$ and were inocculated into enriched thioglycollate broth containing haemin $5 \mathrm{mg} / \mathrm{L}$ and vitamin $\mathrm{K}$ $\mathrm{mg} / \mathrm{L}(18)$. The plates were incubated in Gas-Pak jars (BB, Cockeysville, MD) and examined after 48 and $96 \mathrm{~h}$. The thioglycollate broth was incubated for 14 days. Aerobic and anaerobic bacteria were identified by conventional techniques $(14,18)$.

\section{RESULTS}

Bacteria grew from 63 (69\%) of 91 specimens examined, Either aerobic or facultative anaerobic bacteria only were present in $12(19 \%)$ of the 63 specimens, anaerobic bacteria only in $10(16 \%)$, and mixed aerobic and anaerobic bacteria in 41 (65\%) (Table 1). The average number of isolates from infected tumours was 2.1 (range 1-5). The highest average number of isolates was from pelvic, lymphatic and breast tumours (2.6-3/ specimen). A total of 83 isolates of anaerobic bacteria (average 1.3 isolates/specimen) and 47 of aerobic and facultative anaerobic bacteria (average 0.7 isolates/specimen) were obtained (Table 2.). The predominant anaerobic bacteria were Bacteroides spp. (36 isolates, including 17 from the $B$. fragilis group), anaerobic grampositive cocci (20 isolates), and Propionibacterium acnes (22 isolates, 12 from tumours of the head and neck). Seven of the 22 P. acnes isolates grew in thioglycollate broth only. The commonest aerobic and facultative anaerobic bacteria isolated were Staphylococcus aureus. $a$ haemolytic streptococci and Escherichia coli (seven isolates each), and S. epidermidis, Klebsiella pneumoniae, and Pseudomonas aeruginosa (five isolates each).

Using Student' s t test statistically significant differences were not found in the number or diversity of organisms isolated from 16 different anatomical sites nor was there any correlation between the bacterial species isolated and the sites of the tumours, except for increased isolation organisms of the $B$. fragilis group from abdominal tumours ( 8 of 17 isolates), and of $P$. acnes from tumours of the head and neck (all of 12 isolates). However, significantly fewer organisms were isolated from patients who had received antimicrobial (38 isolates from 28 patients, 1.4 isolates/specimen than in patients who had not received antimicrobials (92 isolates from 35 patients, 2.6 isolates/specimen). None of the $17 \mathrm{~B}$. fragilis group isolates were from patients who had received clindamycin.

Table 1 Characteristics of 63 Infected Solid Tumours

\begin{tabular}{|c|c|c|c|c|c|c|c|c|c|}
\hline \multirow[b]{2}{*}{$\begin{array}{l}\text { Tumour } \\
\text { Sites }\end{array}$} & \multirow[b]{2}{*}{$\begin{array}{l}\text { Number of } \\
\text { Specimens }\end{array}$} & \multirow[b]{2}{*}{$\begin{array}{c}\text { Number of } \\
\text { Anaerobic } \\
\text { Isolates }\end{array}$} & \multirow[b]{2}{*}{$\begin{array}{c}\text { Number of } \\
\text { Aerobic } \\
\text { Isolates }\end{array}$} & \multirow[b]{2}{*}{$\begin{array}{c}\text { Anaerobic/ } \\
\text { Sample }\end{array}$} & \multirow[b]{2}{*}{$\begin{array}{c}\text { Aerobic/ } \\
\text { Sample }\end{array}$} & \multirow[b]{2}{*}{$\begin{array}{c}\text { Isolates/ } \\
\text { Sample }\end{array}$} & \multicolumn{3}{|c|}{ Number (\%) of Samples with } \\
\hline & & & & & & & $\begin{array}{c}\text { Anaerobic } \\
\text { Only }\end{array}$ & $\begin{array}{c}\text { Aerobic } \\
\text { Only }\end{array}$ & $\begin{array}{l}\text { Anaerobic } \\
+ \text { Aerobic }\end{array}$ \\
\hline Abdomen & 14 & 17 & 13 & 1.2 & 0.9 & 2.1 & $3(21)$ & $1(7)$ & $10(71)$ \\
\hline Pelvis & 5 & 9 & 4 & 1.8 & 0.8 & 2.6 & $1(20)$ & 0 & $4(80)$ \\
\hline Head and neck & 23 & 26 & 15 & 1.1 & 0.7 & 1.8 & $3(13)$ & $7(30)$ & $13(57)$ \\
\hline Lung & 4 & 4 & 4 & 1.0 & 1.0 & 2.0 & $1(25)$ & $1(25)$ & $2(50)$ \\
\hline Mediastinum & 4 & 4 & 3 & 1.0 & 0.7 & 1.7 & 0 & $1(25)$ & $3(75)$ \\
\hline Lymphatic & 2 & 4 & 2 & 2.0 & 1.0 & 3.0 & 0 & 0 & $2(100)$ \\
\hline Breast & 3 & 7 & 2 & 2.3 & 0.7 & 3.0 & $1(33)$ & 0 & $2(67)$ \\
\hline Miscellaneous & 8 & 12 & 4 & 1.5 & 0.5 & 2.0 & $1(12)$ & $2(25)$ & $5(63)$ \\
\hline Total & 63 & 83 & 47 & 1.3 & 0.7 & 2.1 & $10(16)$ & $12(19)$ & $41(65)$ \\
\hline
\end{tabular}


Table 2 Frequency of Isolation of Aerobic and Anaerobic Bacteria from 63 Specimens from Infected Solid Tumours

\begin{tabular}{|c|c|c|c|c|c|c|c|c|c|}
\hline \multirow[b]{2}{*}{$\begin{array}{l}\text { Species of } \\
\text { Bacteria }\end{array}$} & \multicolumn{9}{|c|}{ Number of Isolates from Tumours of } \\
\hline & $\begin{array}{l}\text { Abdomen } \\
(14)^{*}\end{array}$ & $\begin{array}{l}\text { Pelvis } \\
(5)\end{array}$ & $\begin{array}{c}\text { Head and } \\
\text { Neck } \\
(23)\end{array}$ & $\begin{array}{l}\text { Lung } \\
\text { (4) }\end{array}$ & $\begin{array}{l}\text { Mediastinum } \\
\text { (4) }\end{array}$ & $\begin{array}{l}\text { Lymphatics } \\
\text { (2) }\end{array}$ & $\begin{array}{l}\text { Breast } \\
(3)\end{array}$ & $\begin{array}{l}\text { Miscel- } \\
\text { Laneous } \\
(8)\end{array}$ & $\begin{array}{l}\text { Total } \\
(63)\end{array}$ \\
\hline \multicolumn{10}{|l|}{ Aerobic and facultative } \\
\hline Streptococcus pyogenes & - & - & 2 & - & - & 1 & - & - & 3 \\
\hline Str, faecalis & 2 & - & - & - & - & - & - & - & 2 \\
\hline $\begin{array}{l}\text { a-haemolytic strepto } \\
\text { coccus }\end{array}$ & - & - & 2 & 1 & 1 & - & 1 & 2 & 7 \\
\hline Staphylococcus atureus & - & 1 & 3 & - & 2 & - & 1 & - & 7 \\
\hline S. epidermidis & 1 & - & 4 & - & - & - & - & - & 5 \\
\hline Escheria coli & 4 & 2 & - & - & - & 1 & - & - & 7 \\
\hline Klebsiella pneumoniae & 1 & 1 & 1 & 2 & - & - & - & - & 5 \\
\hline Klebsiella oxytoca & 2 & - & - & - & - & - & - & - & 2 \\
\hline Acinetobacter sp. & - & - & - & - & - & - & - & 1 & 1 \\
\hline Serrana marcescens & 1 & - & - & - & - & - & - & 1 & 2 \\
\hline $\begin{array}{l}\text { Pseudomonas aerugi } \\
\text { nosa }\end{array}$ & 2 & - & 3 & - & - & - & - & - & 5 \\
\hline $\begin{array}{l}\text { Micro-aerophilic } \\
\text { streptococcus }\end{array}$ & - & - & - & 1 & - & - & - & - & 1 \\
\hline Anaerobic & & & & & & & & & \\
\hline Peptostreptococcus sp. & 2 & 1 & 2 & 1 & - & 1 & 1 & - & 8 \\
\hline P. preuotii & - & - & 2 & - & - & - & 1 & - & 3 \\
\hline P. anaerobius & - & - & 1 & - & - & - & - & 1 & 2 \\
\hline P. magnus & - & - & 3 & 1 & - & - & 2 & 1 & 7 \\
\hline Veillonella sp. & - & 1 & - & - & - & - & - & - & 1 \\
\hline Bifidobacterium $s p$ & - & - & 1 & - & - & - & - & - & 1 \\
\hline Eubacterium $s p$ & - & - & - & - & - & - & - & - & 1 \\
\hline Propionibacterium acnes & 1 & 1 & 12 & - & 4 & -- & - & 4 & 22 \\
\hline Clostridium sp. & 1 & - & - & - & - & - & - & - & 1 \\
\hline Fusobacterium sp. & - & 1 & - & - & - & - & - & - & 1 \\
\hline Bacteroides sp. & 2 & 1 & 1 & 1 & - & 1 & - & - & 6 \\
\hline B. fragilis & 5 & 1 & 2 & 1 & - & 1 & 1 & 2 & 13 \\
\hline B. obatus & 1 & - & - & - & - & - & - & - & \\
\hline B. thetaiotaomicron & 2 & 1 & - & - & - & - & - & - & 3 \\
\hline B. melaninnogenicus & 2 & - & - & - & - & 1 & 2 & 3 & 8 \\
\hline B. oralis & 1 & - & - & - & - & - & - & - & 1 \\
\hline B. oris-buccae & - & 1 & - & - & - & - & - & - & 1 \\
\hline B. loescheii & - & 1 & 1 & - & - & - & - & - & 2 \\
\hline B. ureolyticus & - & - & 1 & - & - & - & - & - & 1 \\
\hline
\end{tabular}

*No.of specimens

\section{DISCUSSION}

The results of this study demonstrate that anaerobic bacteria are often present in infected solid tumours and support the findings (16) who isolated anaerobic predominantly from infected malignant ulcers in 70 patients of a total of 282 isolates, 179 (63\%) were anaerobes. Furture sup- port for the importance of anaerobic bacteria in infections of solid tumours comes from the effect of anti-anaerobe antimicrobial agents. In the present study, organisms of the $B$. fragilis group were not isolated from infected tumours in patients who had been treated with clindamycin. Similar findings have been described $(3,11,12$, 13 , 17) although the detailed microbiology of 
infected tumours was not described in these studies.

The anaerobes isolated from infected tumours probably originate from mucous membranes adjoining the tumour site, so explaining the predominance of organisms of the $B$. fragilis group in infected abdominal tumours and the distribution of other anaerobes in different sites.

The frequent isolation of anaerobes from infected tumours is not surprising because, when tumours outgrow their blood supply and become necrotic, the resulting lowered oxygen tension may favour the growth of anaerobes (6). Anaerobic glycolysis is also significantly increased in tumour tissue, with a resulting accumulation of lactic acid in the tissue and its environment.

Spores of non-pathogenic Clostridium spp. can localise and germinate in neoplasms and produce extensive lysis of tumours without concomitant effect on normal tissue (Malmgren and Flanigan, an infection within tumour lesions has been reported $(1,8,9)$.

Synergy between the various bacteria that may be found in infected tumours has been demonstrated in patients as well as in animal models. Such synergy between anaerobic and aerobic bacteria causes mutual enhancement of growth (5), abscess formation and increased mortality in animals $(2,7,10)$.

Polymicrobial aerobic annd anaerobic infection in a necrotic tumour may represent a serious threat removal or evacuation of pus should be complemented by antimicrobial therapy directed at the eradication of the anaerobic as well as the aerobic flora present.

\section{REFERENCES}

1. Alpern RJ, Dowell VR (1969) Clostridum septicum infection and malignancy. J. Am. Med. Associ. 209, 385-388.

2. Altemier W A (1942) The pathogenicoity of the bacteria of appendicitis peritonitis; experimental study. Surgery II,
374-384.

3. Ashby E C, Rees M, Dowdinng CH (1978) Prophylaxis against systemic infection after transrectal biopsy for suspected prostati carcinoma. Brit. Med. J. II, 1263-1264.

4. Bodey GP(1986) Infection in cacer patients. A continuing association. Am. J. Med. 81 Supp. I A 11-26.

5. Brook I (1985) Enhancemeent of growth of aerobic and facultative bacteria in mixed infections with Bacteroides species. Inf. Imm. 50, 929-931.

6. Brook I (1989) Pediatric anaerobic infection: diagnosis and management. C.V. Mosby Co., St Louis, MO.

7. Brook I, Hunter V, Walker RI (1984) Synergistic effect of Bacteroides, Clostridium, Fusobacterium, anaerobic cocci, and aerobic bacteria on mortlity and inbuction of subcutaneous abscesses in mice. J. Inf. Dis. 149, 924-928.

8. Cabrea A, Tsukada Y, Pickren JW (1965) Clostridial gas gangrene and septicemia in malignant disease. Cancer 18, 800-806.

9. Caya JG et al. (1986) Clostridial septicemia complication in the course of leukemia. Cancer 57, 2045-2048.

10. Hite KE, Locke M, Hesseltine HC (1949) Synergism in experimental infection with nnonsporulating anaerobic bacteria. J. Inf. Dis. 84, 1-9.

11. Klastersky J, Coppens L, Mombelli G (1979) Anaerobic infection in cancer patients: comparative evaluations of clindamycin and cefoxitin. Antimic. Agents Chemother. 16, 366-371.

12. Klastersky J Husson M, Weerts Ruhl D, Danneau D (1979) Anaerobic wound infections in cancer patients: comperative trial of clindamycin, tinidazole and doxycycl. Antimic. Agents Chemother. 12, 563-570.

13. Lagast H, Klastersky $J$ (1982) Anerobic infections in cancer patients-3 retrospective analysis of clindamycin, tinidazole, doxycyclin, cefoxitin and moxalactam. Infection 19, 144-148.

14. Lennette E H, Balows A, Hausler W J, Shadomy H J (eds) (1985) Manual of clinical microbiology 4th edn. American Society for Microbiology, Washington, DC.

15. Malmgren RA, Flanigan CC (1955) Localization of the vegetativ form of Clostridium tetani in miuse tumours following intravenous spore administration, Cancer Rese. 15, 473-478.

16. Rotimi VO, Durosinmi-Etti F.A (1984) The bacteriology infected malignant ulcers. J. Clin. Pathol. 37, 592-595.

17. Sinkovics JG.Smith JP (1970) Septicemia with bacteroides in patients with malignant disease Cancer 25, 663-671.

18. Sutter VL Citron DM, Edelstein MAC, Finegold S M (1989), Wadswirth anaerobic bacteriology manual, 4th edn. Star Publishing Co., Belmont, CA. 